\title{
Effects of follicle stimulating hormone, cholera toxin, pertussis toxin and forskolin on adenosine cyclic 3',5'-monophosphate output by granulosa cells from Booroola ewes with or without the $F$ gene
}

\author{
K. P. McNatty, S. Lun, N. L. Hudson and S. Forbes \\ MAFTech. Wallaceville Animal Research Centre, Ministry of Agriculture and Fisheries, \\ P.O. Box 40063, Upper Hutt, New Zealand
}

Summary. The cAMP outputs by granulosa cells from 3-4.5 mm diameter (medium) follicles of Booroola FF ewes were similar to those by cells from $\geq 5 \mathrm{~mm}$ diameter (large) follicles of ++ ewes with respect to time or dose of $\mathrm{FSH}$, cholera toxin or forskolin. Likewise, the cAMP outputs by cells from $1-2.5 \mathrm{~mm}$ diameter (small) FF follicles were similar to those by cells from small and medium ++ follicles with respect to time or dose of $\mathrm{FSH}$, cholera toxin or forskolin. At $\mathrm{FSH}$, cholera toxin or forskolin doses of $1 \mu \mathrm{g} / \mathrm{ml}, 0.5 \mu \mathrm{g} / \mathrm{ml}$ and $10^{-4} \mathrm{M}$ respectively, the granulosa cell cAMP outputs of medium FF or large ++ follicles were approximately 2 -fold $(P<0.05)$ higher than in the respective small FF and medium ++ follicles. The effects of cholera toxin plus forskolin or FSH plus forskolin were additive irrespective of genotype or follicle size, with significant differences $(P<0.05)$ observed between follicle sizes but not genotype. No differences were noted between cholera toxin plus forskolin or FSH plus forskolin on granulosa cell cAMP output.

For the FSH and forskolin treatments, increased mean cAMP outputs were evident after $10 \mathrm{~min}$, whereas after cholera toxin treatment they were not evident until after 20 min incubation. For all treatments the rate of cAMP production tended to slow down after $40-60 \mathrm{~min}$.

Pre-incubation of granulosa cells with pertussis toxin subsequently resulted in a significantly greater $(P<0.05) \mathrm{FSH}$-induced output of cAMP relative to the untreated controls irrespective of follicle size. However, no gene-specific differences were noted when the cAMP outputs of cells from medium or small FF follicles were compared with cells from large or small-medium ++ follicles respectively.

These results indicate that the activity (or composition) of the regulatory and catalytic components of adenylate cyclase in the FF granulosa cells change in a manner similar to those observed in ++ cells with the only difference being that the increases in cyclase in FF ewes occurs as follicles enlarge from $1-2.5$ to $3-4.5 \mathrm{~mm}$ in diameter, whereas in ++ ewes they occur as follicles enlarge from $3-4 \cdot 5$ to $\geq 5 \mathrm{~mm}$ in diameter. No evidence was found to link the F gene to the granulosa cell cAMP response independently of follicle size. It is suggested that the association between the $F$ gene and the size-specific difference in follicle maturation may be unrelated to the FSH receptor/cAMP generating system.

Keywords: FSH; cholera toxin; pertussis toxin; forskolin; cAMP; granulosa cells; Booroola ewes; F gene

\section{Introduction}

High fecundity Booroola ewes carry a major gene(s) which influences the number of ovulations per oestrous cycle (i.e. ovulation rate; see Bindon, 1984, for review). Homozygous (FF) and 
heterozygous $(\mathrm{F}+)$ carriers and non-carriers $(++)$ of the $\mathrm{F}$ gene(s) have been segregated by pedigree and by ovulation-rate recordings of $\geq 5,3$ or 4 , and 1 or 2 respectively (Davis et al., 1982). The endocrine basis for the high ovulation rate remains unknown. A characteristic feature of animals with the $F$ gene is that their ovarian follicles ovulate at a significantly smaller diameter than do those in ++ ewes (McNatty et al., 1986a). In FF ewes preovulatory-sized follicles have diameters of 3$4.5 \mathrm{~mm}$ whereas in ++ ewes such follicles have diameters exceeding $5 \mathrm{~mm}$. This size difference before ovulation seems to be a consequence of antral follicles in $F$ gene carriers responding to luteinizing hormone ( $\mathrm{LH})$ and/or follicle stimulating hormone (FSH) to synthesize high levels of adenosine cyclic 3',5'-monophosphate (cAMP) and of granulosa cells in F gene carriers synthesizing oestradiol and acquiring functional LH receptors at smaller diameters relative to those in ++ animals (Henderson et al., 1985, 1987; McNatty et al., 1985a, b, 1986a, b, 1989a). This earlier sensitivity to $\mathrm{FSH}$ (or $\mathrm{LH}$ ) or the presence of more differentiated cells with respect to cAMP synthesis is not due to any obvious gene-specific differences in the FSH (or LH) binding characteristics of the granulosa cells (McNatty et al., 1986a, 1989a) or to any change in cAMP-phosphodiesterase activity (McNatty et al., 1989b). However, it might be due, in part, to increased activity or altered composition of the regulatory or catalytic components of the adenylate cyclase system (Richards \& Hedin, 1988).

It is thought that FSH (or LH) modulation of adenylate cyclase (EC 4.6.1.1) occurs following FSH (or LH) receptor binding via a pair of regulatory guanine-nucleotide-binding (GTP) proteins Gs and $\mathrm{Gi}$, whereby Gs mediates stimulation and $\mathrm{Gi}$ inhibition of the catalytic component of the adenylate cyclase system (see Gilman, 1984, for review). The activities of the regulatory $G$ proteins have been assessed using the bacterial toxins, cholera or pertussis toxin, which specifically ADPribosylate the s or i chains of the respective G proteins (Birnbaumer et al., 1985; Jakobs et al., 1985; Schram \& Selinger, 1986). For example, in pig granulosa cells, cholera toxin can stimulate cAMP synthesis in the absence of pituitary hormones while preincubation of granulosa cells with pertussis toxin can subsequently enhance the ability of FSH or LH to stimulate cAMP synthesis (Veldhuis \& Hewlett, 1985). The effects of cholera or pertussis toxin on cAMP synthesis in sheep granulosa cells are not known.

The activity of the catalytic component of adenylate cyclase can, at least in part, be evaluated using forskolin (Gilman, 1984; Seamon, 1985). At micromolar concentrations, forskolin has been shown to stimulate adenylate cyclase in the absence of Gs (Seamon et al., 1981) although in intact cells such as the membrana granulosa forskolin may stimulate cAMP synthesis via two separate binding sites: one class of binding site may be associated with the catalytic component of cyclase, while the other might be via the Gs cyclase complex (Seamon \& Daly, 1985).

To gain further information on the regulation of granulosa-cell cAMP synthesis in Booroola ewes we have examined the effects of different doses and/or incubation times of FSH, cholera toxin, pertussis toxin, forskolin or cholera toxin plus forskolin on granulosa cells from non-atretic follicles from the FF and ++ genotypes.

\section{Materials and Methods}

\section{Animals}

The parous Booroola Merino ewes were between 4 and 8 years of age. All the $\mathrm{FF}(\mathrm{N}=38)$ and $++(\mathrm{N}=38)$ animals were assigned their genotype by pedigree analysis. Moreover, at least one annual examination of ovulation rate in these animals by laparoscopy confirmed that the ovulation rates in $\mathrm{FF}$ and ++ ewes were $\geq 5$ and $<3$ respectively. Ovaries of the Booroola ewes were recovered between Day 4 and Day 12 of the oestrous cycle (Day $0=$ day of oestrus).

\section{Recovery of granulosa cells and assay methodology}

Ovaries were collected into chilled minimum essential medium (MEM; Gibco, Grand Island, NY, USA) + 20 mMHepes buffer (Sigma Chemical Co., St Louis, MO, USA) $+0 \cdot 1 \%$ (w/v) BSA ( $>97 \%$ pure; Immuno-chemical Products Ltd, Auckland, NZ). All follicles ( $\geq 1 \mathrm{~mm}$ diam.) were dissected free of extraneous tissue. Granulosa cells were 
pooled from non-atretic follicles of $1-2.5 \mathrm{~mm}, 3-4.5 \mathrm{~mm}$ or $\geq 5 \mathrm{~mm}$ in diameter (see McNatty et al., 1986a, for the follicle classification system). Briefly, a non-atretic follicle was defined as that which contained a vascularized theca interna, no debris in follicular fluid, $\geq 25 \%$ of the maximum number of granulosa cells for a given follicle size and an oocyte of healthy appearance. An atretic follicle was so defined if one or more of the above criteria were not satisfied. For each genotype, each pool of granulosa cells was made from the ovaries of 2 ewes except for the time course studies for which pools of cells were prepared from single ewes. Once prepared, the cellular pools were centrifuged at $450 \mathrm{~g}$ at $4-6^{\circ} \mathrm{C}$ for $20 \mathrm{~min}$ and the cellular pellets were then resuspended in the incubation medium, namely $\mathrm{MEM}+$ bovine insulin $(2 \mu \mathrm{g} / \mathrm{ml}$; Gibco $)+$ cortisol $(40 \mathrm{ng} / \mathrm{ml}$; Sigma $)+3$-isobutyl-1-methylxanthine $(0 \cdot 2 \mathrm{mM}$, IBMX; Sigma $)+$ Hepes buffer $(20 \mathrm{~mm})+0 \cdot 1 \%(\mathrm{w} / \mathrm{v})$ BSA at a concentration of $2-4 \times 10^{5} \mathrm{cells} / \mathrm{ml}$. For the doseresponse studies with FSH (NIADDK-oFSH-16), cholera toxin (Calbiochem, La Jolla, CA, USA) or forskolin (Calbiochem), the cell suspensions were then added in $0.5 \mathrm{ml}$ aliquants to $12 \times 75 \mathrm{~mm}$ screw-topped plastic tubes semi-immersed in ice-water and containing $0.5 \mathrm{ml}$ of the above incubation medium with FSH $(0,20,200$ or $2000 \mathrm{ng} / \mathrm{ml})$, cholera toxin $(10,100$ or $1000 \mathrm{ng} / \mathrm{ml})$ or forskolin $\left(2 \times 10^{-6}, 2 \times 10^{-5}\right.$ or $\left.2 \times 10^{-4} \mathrm{M}\right)$. All the doseresponse studies on each pool of cells were performed in duplicate. The tubes were incubated at $37^{\circ} \mathrm{C}$ for 0 or $45 \mathrm{~min}$ and then heated to $80^{\circ} \mathrm{C}$ for $15 \mathrm{~min}$ before being stored at $-20^{\circ} \mathrm{C}$ until assayed for cAMP.

The effects of incubation time on the rates of cAMP synthesis by granulosa cells from FF and ++ ewes were also tested after exposure to FSH $(100 \mathrm{ng} / \mathrm{ml}$ final concentration), cholera toxin $(500 \mathrm{ng} / \mathrm{ml}$ final concentration) or forskolin $\left(10^{-4} \mathrm{M}\right.$ final concentration). As described above, the cells in $0.5 \mathrm{ml}$ incubation medium were added to $10 \times 75 \mathrm{~mm}$ tubes containing $0.5 \mathrm{ml} \mathrm{FSH}$, cholera toxin or forskolin and then incubated for $0,10,20,40,60,120$ or $240 \mathrm{~min}$ followed by heating to $80^{\circ} \mathrm{C}$.

For the studies with pertussis toxin (Batch 87-2; Commonwealth Serum Laboratories, Melbourne, Australia) $0.5 \mathrm{ml}$ aliquants of cells were added to $12 \times 75 \mathrm{~mm}$ screw topped plastic tubes as described above containing either $0.5 \mathrm{ml}$ incubation medium alone or $0.5 \mathrm{ml}$ incubation medium with $400 \mathrm{ng}$ pertussis toxin/ml. The tubes were then incubated overnight (i.e. $16 \mathrm{~h}$ ) in an agitating waterbath at $37^{\circ} \mathrm{C}$. The following day the tubes were centrifuged at $450 \mathrm{~g}$ for $20 \mathrm{~min}$ at $4-6^{\circ} \mathrm{C}$. The resulting supernatant was then discarded and the cellular pellet resuspended in fresh incubation medium containing $1000 \mathrm{ng} \mathrm{FSH} / \mathrm{ml}$ (NIADDK-oFSH-16) and incubated at $37^{\circ} \mathrm{C}$ for 0 or $45 \mathrm{~min}$ followed by heating at $80^{\circ} \mathrm{C}$ as described above. The numbers of cells at the end of the pertussis experiment were determined by the DNA assay of Sorger \& Germinario (1983).

To test for additive or synergistic effects of cholera toxin plus forskolin on cAMP synthesis with respect to genotype, $0.5 \mathrm{ml}$ cholera toxin at $1 \mu \mathrm{g} / \mathrm{ml}$, forskolin at $2 \times 10^{-4} \mathrm{M}$ or cholera toxin $(1 \mu \mathrm{g} / \mathrm{ml})$ plus forskolin $\left(2 \times 10^{-4} \mathrm{M}\right)$ were added to granulosa cells $\left(1-2 \times 10^{5} /\right.$ tube $)$ in $0.5 \mathrm{ml}$ and incubated for 0 or $45 \mathrm{~min}$, followed by heating to $80^{\circ} \mathrm{C}$.

\section{cAMP assay}

The assay was similar to that described by McNatty et al. (1985b). Briefly, 10-100 $\mu$ lincubation medium and standards were added to assay tubes $(12 \times 75 \mathrm{~mm}$ ), acetylated (Harper \& Brooker, 1975) and then incubated with $100 \mu$ l cAMP antiserum (ARL; kindly supplied by Dr A. R. La Barbera, Northwestern University, Chicago, IL, USA) and $100 \mu{ }^{125}$ I-labelled 2',0-monosuccinyl adenosine $3^{\prime}, 5^{\prime}$-cyclic monophosphate tyrosyl methyl ester (unlabelled material supplied by Sigma) at $4^{\circ} \mathrm{C}$ overnight. Subsequently, the free and bound fractions were separated using $0.2 \%$ $(\mathrm{w} / \mathrm{v})$ activated charcoal (Sigma) in $0.05 \mathrm{M}$-sodium acetate buffer $(\mathrm{pH} 6.5)$ with $0.25 \%(\mathrm{w} / \mathrm{v}) \mathrm{BSA}$. With the above procedure the assay measures total cAMP, that is both the intra- and extra-cellular content. Examination of residual cell numbers in the assay tubes after incubation at $37^{\circ} \mathrm{C}$, heating to $80^{\circ} \mathrm{C}$ and freezing and thawing revealed $<25 \%$ of the original cell numbers remained with most identifiable cells being damaged and/or fragmented. Also, no significant differences in cAMP values were noted after comparing the results of the above assay with those after the media and cells had been sonicated to disintegrate all residual granulosa cells (paired $t$ test; $n=12$ separate pools of cells/ genotype). The cAMP results were expressed as pmol $/ 10^{6}$ cells with the inter-and intra-assay coefficients of variation being 14 and $8 \%$ respectivly. The limit of detection was $<0.02 \mathrm{pmol} / 10^{6}$ cells.

\section{DNA assay}

DNA (calf thymus; Sigma) standards in the range 0.35-3.5 $\mu \mathrm{g}$ DNA $/ \mathrm{ml}$ were prepared in the aforementioned incubation medium. Aliquants $(200 \mu \mathrm{l})$ of DNA standard or cellular material were added to glass test tubes $(12 \times 75 \mathrm{~mm})$. Subsequently $2.5 \mathrm{ml}$ diamidinephenylindole solution DAPI (Sigma) were added. The DAPI solution was prepared by combining 0.4 volumes DAPI $(2.5 \mu \mathrm{g} / \mathrm{ml})$ in 3.6 volumes of assay buffer $\left(18 \mathrm{~mm}-\mathrm{NaSO}_{4}+50 \mathrm{~mm}-\right.$ Hepes, $\mathrm{pH} 7.0$ ) and 6 volumes of water. After incubation for $10 \mathrm{~min}$ at room temperature, the relative fluorescence values of the unknowns were compared with the standards using a Perkin Elmer 2000 Fluorescence Spectrophotometer with a $360 \mathrm{~nm}$ excitation and $450 \mathrm{~nm}$ emission filter and the expansion multiplier set on $\times 50$.

\section{Statistical analyses}

No significant departures from normality were noted using the Kolmorgorov-Smirnov test (Zar, 1974). However, the data were transformed using $\log _{\mathrm{e}}$ to equalize the variances. To examine the effects of FSH, cholera toxin or forskolin on cAMP output, multiple linear regressions were performed for each reagent separately to examine the 
overall contribution of genotype, follicular diameter and dose or time to the variation in cAMP response. For each genotype, the effects of dose or time for each diameter were tested by least squares regression analysis whereas the effects of follicular diameter at each dose were tested by paired-sample $t$ test. For the regression analyses, indicator variables were used to model genotype, follicular diameter (1,2,3 for small, medium, large respectively) and dose ( 1 , 2,3 for increasing levels). In some cases follicles of different sizes and genotype were judged to be at similar stages of development. Subsets of the data were then analysed as indicated. For genotype comparisons, multiple $t$ tests were performed between pairs of follicle groups.

To test for differences between the pertussis toxin and control groups or between forskolin and/or cholera toxin and forskolin + cholera toxin, paired $t$ tests were used for comparisons within each genotype and the dose and follicular diameter genotype effects between pairs of follicle groups were performed by multiple $t$ tests.

\section{Results}

In the ++ genotype, non-atretic follicles $\geq 5 \mathrm{~mm}$ in diameter were common (i.e. $1 \cdot 2 \pm 0 \cdot 2$ follicles per ewe; $\mathrm{N}=38$ animals), but in the $\mathrm{FF}$ genotype follicles $\geq 5 \mathrm{~mm}$ diameter were never observed irrespective of whether they were atretic or non-atretic. The largest non-atretic follicles in the FF genotype were $3-4 \cdot 5 \mathrm{~mm}$ in diameter (i.e. $3 \cdot 2 \pm 0 \cdot 3$ per ewe, $\mathrm{N}=38$ ). In the ++ genotype, the mean \pm s.e.m. number of non-atretic $3-4.5 \mathrm{~mm}$ follicles was $2.6 \pm 0.5$ per ewe. The mean \pm s.e.m. numbers of non-atretic follicles of $1-2.5 \mathrm{~mm}$ diameter in $\mathrm{FF}$ and ++ genotypes were $9.3 \pm 0.8$ per ewe and $9.5 \pm 0.7$ per ewe respectively.

\section{Effect of FSH, cholera toxin or forskolin on cAMP output by granulosa cells with respect to dose, follicular diameter and Booroola genotype}

These data summarized as geometric means (and $95 \%$ confidence limits) are shown in Fig. 1. For FSH and forskolin there were statistically significant positive associations between dose and granulosa cell cAMP output for all follicle diameters $(P<0.05$ for both hormones, linear regression analysis, $R>0.6, \mathrm{~N}=10$ sheep). For cholera toxin, the associations were not significant ( $P>0.05, R \sim 0.5$ for all follicular diameters, $\mathrm{N}=10$ sheep).

When cells from $\geq 5 \mathrm{~mm}$ diameter (large) ++ and $3-4.5 \mathrm{~mm}$ diameter (medium) FF follicles were each considered to be at a similar stage of maturation and those from medium ++ and 1-2.5-mm (small) FF follicles were each considered to be at similar stages, multiple linear regression analysis indicated that the dose of FSH, cholera toxin or forskolin accounted for between 69 and $86 \%$ of the cAMP variation, whereas follicular diameter and genotype respectively accounted for between 3 and $10 \%$ and 0.1 and $0.7 \%$ of the variation.

For all doses of FSH, cholera toxin or forskolin, the mean cAMP outputs by cells from medium $\mathrm{FF}$ follicles were all significantly greater $(P<0.05)$ than those from small $\mathrm{FF}$ follicles. For the ++ genotype at all doses of FSH or forskolin $\geq 10^{-5} \mathrm{M}$ respectively, the mean cAMP outputs by granulosa cells from large follicles were all greater $(P<0.05)$ than those from either medium or small follicles with the outputs from cells from the last two follicle sizes not being different from one another. For cholera toxin at all doses, the mean cAMP outputs by cells from large ++ follicles were greater $(P<0.05)$ than those by cells from small ++ follicles but not from medium ++ follicles (Fig. 1).

With regard to genotype comparisons, no significant differences were noted between cells from large ++ or medium FF follicles at any dose of FSH, cholera toxin or forskolin. For all doses of FSH but not cholera toxin or forskolin, the mean granulosa cell cAMP outputs were significantly greater $(P<0.05)$ from medium $\mathrm{FF}$ than from medium ++ follicles.

\section{Effects of FSH, cholera toxin or forskolin on cAMP output by granulosa cells with respect to follicular diameter, genotype and time}

These data summarized as geometric means (and 95\% confidence limits) are shown in Fig. 2. When the cells from $\geq 5 \mathrm{~mm}$ diameter (large) ++ and $3-4 \cdot 5$-mm diameter (medium) FF follicles 


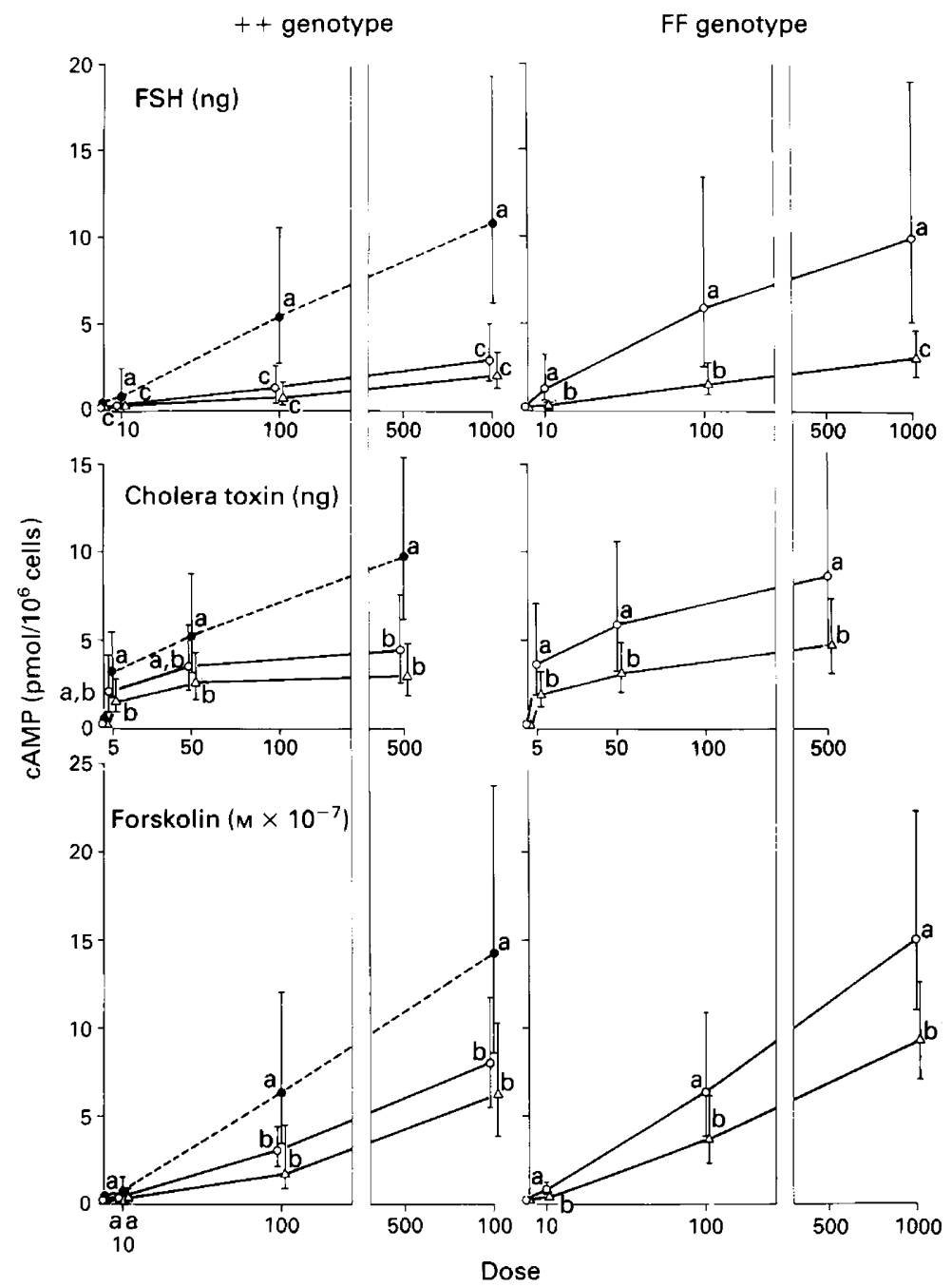

Fig. 1. FSH, cholera toxin and forskolin stimulated cyclic AMP synthesis by granulosa cells from small $(1-2.5 \mathrm{~mm}$ diam.; $\triangle-\triangle)$, medium $(3-4.5 \mathrm{~mm}$ diam.; $\bigcirc-0)$ and large ( $\geq 5 \mathrm{~mm}$ diam.; - -- ) ovarian follicles with respect to dose and Booroola genotype $(++$, $\mathbf{N}=10$ different pools of cell with each pool being derived from 2 ewes; FF, $N=10$ as for ++ ewes). The points represent geometric means with the vertical lines representing the $95 \%$ confidence limits. For all follicle diameters and for all treatments the cAMP outputs in the control incubations were $\leqslant 0.2 \mathrm{pmol} / 10^{6}$ cells. The incubation time was $45 \mathrm{~min}$. For each dose of FSH, cholera toxin or forskolin, the cyclic AMP values not sharing a common alphabetical superscript indicate a significant difference $(P<0.05)$ between follicles of different sizes and/or genotype.

and from 1-4.5-mm diameter (small-medium) ++ and 1-2.5-mm diameter (small) FF follicles were each considered to be at similar stages of maturation, multiple linear regression analysis indicated that the effects of time after FSH, cholera toxin or forskolin accounted for between 60 and $85 \%$ of the cAMP variation whereas follicular diameter and genotype, respectively, accounted for between 2 and $17 \%$ and 0 and $3 \%$ of the variation $(n=5$ pools of cells per genotype for each substance tested). 
For each substance (i.e. FSH, cholera toxin or forskolin) tested, the cAMP response patterns were similar. For the FSH and forskolin treatments, increased mean cAMP outputs were evident after $10 \mathrm{~min}$ relative to the values at time zero, whereas after exposure to cholera toxin, increased mean cAMP outputs were not evident until after $20 \mathrm{~min}$ of incubation. For all treatments the rate of cAMP output tended to slow down after 40-60 min.

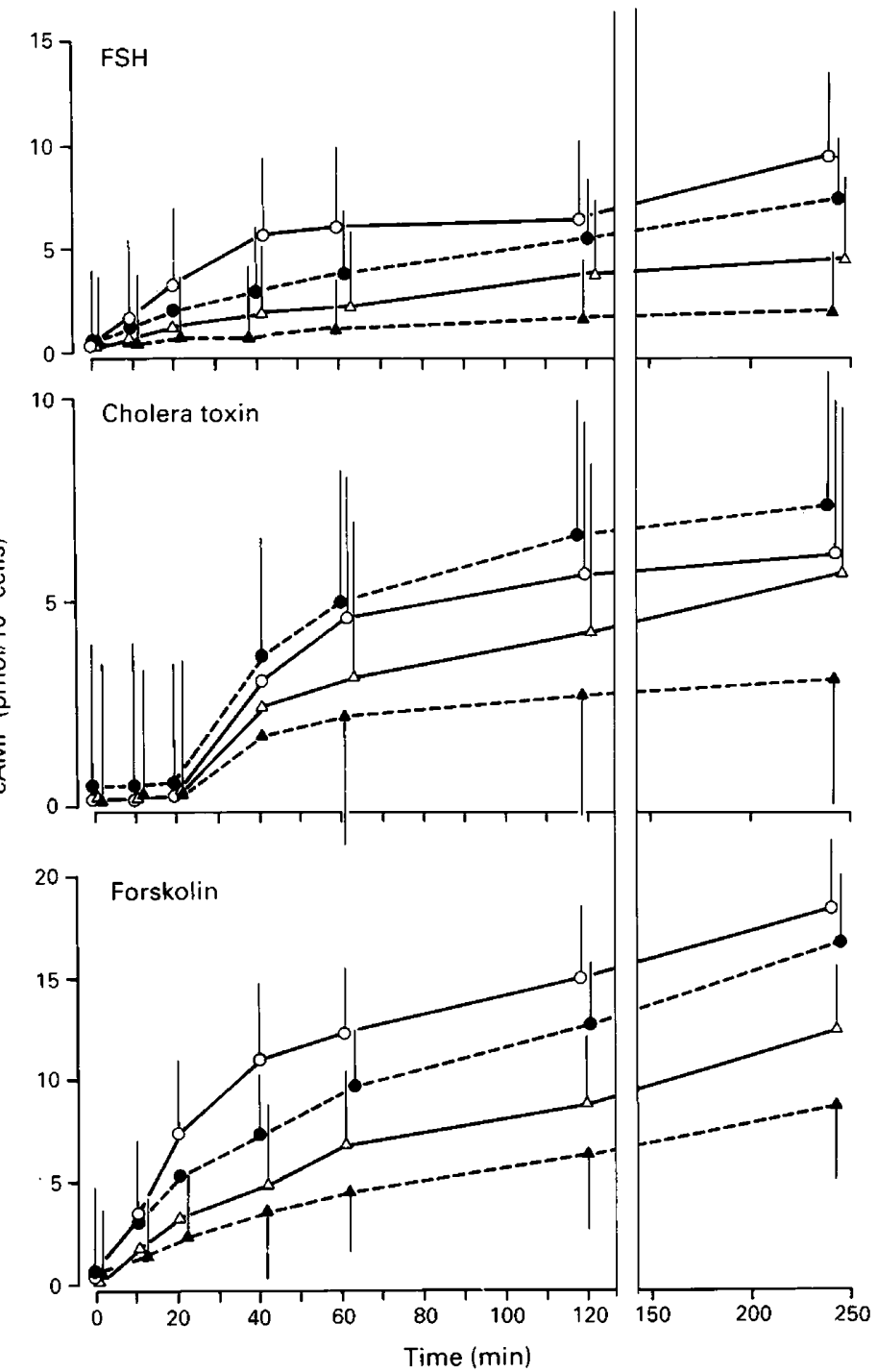

Fig. 2. FSH $(1 \mu \mathrm{g} / \mathrm{ml})$-, cholera toxin $(0.5 \mu \mathrm{g} / \mathrm{ml})$ - or forskolin $\left(10^{-4} \mathrm{M}\right)$-stimulated mean amounts of cAMP produced with respect to follicle diameter $(\mathrm{O}-\mathrm{O} ; 3-4.5 \mathrm{~mm}$ diam. FF: -- $-0 ; \geq 5 \mathrm{~mm}$ diam. $++: \triangle \longrightarrow \triangle$; 1-2.5 mm diam. FF: $\Delta---\Delta ; 1-4.5 \mathrm{~mm}$ diam. $++)$, Booroola genotype and time $(\mathrm{N}=5$ ewes per genotype). Solid vertical lines indicate a change in the time scale.

\section{Effect of pertussis toxin treatment on subsequent FSH-induced cAMP output}

These data with respect to follicular diameter and genotype are summarized in Fig. 3. At all follicular diameters and for both genotypes, preincubation with pertussis toxin resulted in 
significantly more FSH-induced cAMP output relative to that from the controls $(P<0.05$ for all diameters in each genotype; paired $t$ tests). If the FSH-induced outputs from the control or pertussis toxin-treated cells of medium FF follicles are respectively compared to those by cells from large ++ follicles, no gene-specific differences were noted (Student's $t$ test). Likewise, if similar comparisons are made between cAMP outputs from the control or pertussis toxin-treated cells of small FF follicles with those of medium ++ or small ++ follicles, no gene-specific differences were noted ( $n=9$ pools of cells for all treatment groups of both genotypes).

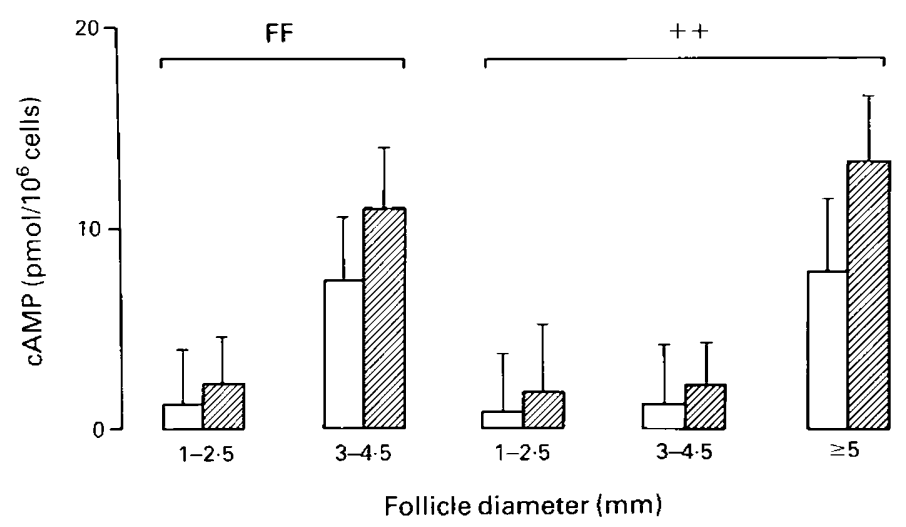

Fig. 3. Mean CAMP outputs from FSH $(1 \mu \mathrm{g} / \mathrm{ml})$-stimulated granulosa cells after overnight preincubation with control medium $(\square)$ or pertussis toxin $(200 \mathrm{ng} / \mathrm{ml} ; \mathbb{Z})$. Values are geometric means with the vertical lines indicating the $95 \%$ confidence limits. In all cases there were significant differences $(P<0.05)$ between the control and pertussis toxin-treated cells (paired $t$ test) at each follicular diameter. $\mathrm{N}=9$ ewes per genotype.

\section{Effects of forskolin, cholera toxin or forskolin + cholera toxin on cAMP output by granulosa cells with respect to Booroola genotype and follicular diameter}

These data are summarized in Table 1. In FF ewes the mean cAMP output by cells from medium follicles (i.e. $3-4.5 \mathrm{~mm}$ diam.) was significantly higher $(P<0.05)$ than that by cells from small follicles (i.e. $1-2.5 \mathrm{~mm}$ diam.) after forskolin or forskolin + cholera toxin treatment but not after cholera toxin treatment alone. In ++ ewes the mean cAMP output by cells from large follicles (i.e. $\geq 5 \mathrm{~mm}$ diam.) was significantly higher $(P<0.05)$ than that by cells from either medium or small follicles after forskolin, cholera toxin or forskolin + cholera toxin treatment.

For each diameter and genotype separately the cAMP outputs after forskolin or cholera toxin treatments were each significantly lower than that of forskolin + cholera toxin (all $P<0.05$; paired $t$ test). However, when the cAMP outputs from the forskolin and cholera toxin treatments were added together they were not significantly different from that of the combined forskolincholera toxin treatments. For both genotypes, therefore, the effects of forskolin plus cholera toxin were additive. Moreover, the cAMP outputs by cells from medium FF follicles were not different from those by cells from large ++ follicles irrespective of treatment. Similarly, the cAMP outputs by cells from small FF follicles were not different from those by cells from medium or small ++ follicles.

The cAMP outputs after cholera toxin $(500 \mathrm{ng} / \mathrm{ml})+$ forskolin $\left(10^{-4} \mathrm{M}\right)$ were compared with those after FSH $(1 \mu \mathrm{g} / \mathrm{ml})+$ forskolin $\left(10^{-4} \mathrm{M}\right)$ and were not significantly different from one another ( $n=4$ pools of cells per genotype per treatment; data not shown). 
Table 1. Effects of cholera toxin, forskolin or cholera toxin + forskolin on cAMP output (geometric means [and $95 \%$ confidence limits] in $\mathrm{pmol} / 10^{6}$ cells) by granulosa cells with respect to Booroola genotype and follicle diameter

\begin{tabular}{|c|c|c|c|c|c|}
\hline \multirow[b]{3}{*}{ Treatment } & \multicolumn{5}{|c|}{ Follicle diameter $(\mathrm{mm})$} \\
\hline & \multicolumn{2}{|c|}{ FF genotype } & \multicolumn{3}{|c|}{++ genotype } \\
\hline & $1-2 \cdot 5$ & $3-4 \cdot 5$ & $1-2 \cdot 5$ & $3-4 \cdot 5$ & $>5$ \\
\hline $\begin{array}{l}\text { Forskolin } \\
\left(10^{-4} \mathrm{M}\right) \\
\text { Cholera toxin } \\
(0 \cdot 5 \mu \mathrm{g} / \mathrm{ml}) \\
\text { Forskolin }\left(10^{-4} \mathrm{M}\right) \\
+ \text { cholera toxin } \\
(0.5 \mu \mathrm{g} / \mathrm{ml})\end{array}$ & $\begin{array}{c}5 \cdot 8^{\mathrm{b}} \\
{[2 \cdot 9,11 \cdot 8]} \\
3 \cdot 5^{\mathrm{a}} \\
{[2 \cdot 1,5 \cdot 7]} \\
11 \cdot 6^{\mathrm{b} *} \\
{[6 \cdot 9,19 \cdot 1]}\end{array}$ & $\begin{array}{c}12 \cdot 1^{\mathrm{a}} \\
{[7 \cdot 2,19 \cdot 9]} \\
5 \cdot 7^{\mathrm{a}} \\
{[3 \cdot 6,8 \cdot 0]} \\
21 \cdot 3^{\mathrm{a} *} \\
{[12 \cdot 4,40 \cdot 1]}\end{array}$ & $\begin{array}{c}4 \cdot 4^{\mathrm{b}} \\
{[2 \cdot 8,6 \cdot 6]} \\
2 \cdot 4^{\mathrm{b}} \\
{[1 \cdot 6,3 \cdot 4]} \\
10 \cdot 6^{\mathrm{b} *} \\
{[7 \cdot 1,15 \cdot 6]}\end{array}$ & $\begin{array}{c}7 \cdot 8^{\mathrm{b}} \\
{[3 \cdot 7,8 \cdot 8]} \\
2 \cdot 2^{\mathrm{b}} \\
{[1 \cdot 3,3 \cdot 3]} \\
10 \cdot 2^{\mathrm{b} *} \\
{[6 \cdot 6,15 \cdot 4]}\end{array}$ & $\begin{array}{c}15 \cdot 2^{\mathrm{a}} \\
{[7 \cdot 6,29 \cdot 4]} \\
5 \cdot 8^{\mathrm{a}} \\
{[2 \cdot 2,9 \cdot 7]} \\
24 \cdot 4^{2 *} \\
{[11 \cdot 8,38 \cdot 4]}\end{array}$ \\
\hline
\end{tabular}

For all follicle diameters and genotypes the control cAMP outputs were $<1 \mathrm{pmol} / 10^{6}$ cells.

$\mathrm{N}=8-13$ ewes/genotype per follicular diameter. For each treatment and each genotype separately, values with a different alphabetical superscript are significantly different from one another $(P<0.05)$.

${ }^{*}$ Forskolin + cholera toxin significantly higher than forskolin or cholera toxin alone $(P<0.05)$.

\section{Discussion}

The major findings from these studies are that the cAMP outputs by granulosa cells from medium (3-4.5 mm diam.) follicles of FF ewes are similar to those by cells from large ( $\geq 5 \mathrm{~mm}$ diam.) follicles of ++ ewes, as are those by cells from small (1-2.5 mm diam.) FF follicles compared to small and medium ++ follicles notwithstanding the dose of FSH, cholera toxin or forskolin. The findings for FSH confirm those of Henderson et al. (1987). Overall, the cAMP output with respect to time tended to be higher in the FF compared to the ++ genotype although the patterns were the same. In addition these studies confirm the existence of a pertussis toxin-sensitive inhibitory component of cAMP production in sheep granulosa cells as has been demonstrated in the pig (Veldhuis \& Hewlett, 1985). However, no evidence for gene-specific differences in the pertussis toxin-sensitive component was noted when the outputs of cells from medium or small FF follicles were respectively compared with cells from large or small-medium ++ follicles. Overall, these findings suggest that the activity (or composition) of the regulatory or catalytic components of the adenylate cyclase system in FF granulosa cells change in a similar manner to those observed in ++ cells with the major difference being that the increase in adenylate cyclase in FF ewes occurs as follicles enlarge from $1-2.5 \mathrm{~mm}$ to $3-4.5 \mathrm{~mm}$ in diameter, whereas in ++ ewes the increase occurs as follicles enlarge from $3-4.5 \mathrm{~mm}$ to $\geq 5 \mathrm{~mm}$ diameter. As this study has confirmed, follicles in FF ewes are rarely observed to enlarge beyond $4.5 \mathrm{~mm}$ in diameter before ovulation, whereas in ++ ewes preovulatory follicles are $\geq 5 \mathrm{~mm}$ in diameter (McNatty et al., 1986a). Since no gene-specific differences have been noted in the FSH- or LH-receptor binding characteristics of sheep granulosa cells or in cAMP phosphodiesterase activity (McNatty et al., $1986 \mathrm{~b}, 1989 \mathrm{a}, \mathrm{b})$, the question remains as to the mechanisms responsible for the size-specific increases in FSH-, cholera toxin- or forskolin-induced cAMP outputs in ++ or FF ewes. Presumably it is this size-specific difference in cAMP response which is ultimately responsible for the gene-specific difference in preovulatory follicular diameter. However, no evidence was obtained from the present study to link the $F$ gene to the size-specific differences in cAMP response. Indeed, any such association between the $F$ gene and the size-specific cAMP response may well be a consequence of a completely different protein or factor(s) influencing ovarian function.

It has been reported that there is an increase in the content of Gs protein in granulosa cells of rat preovulatory follicles as measured by NADP ribosylation of the Gs subunit and quantitation by gel chromatography (unpublished data reported in Richards \& Hedin, 1988). In the present study both 
the cholera toxin- and forskolin-induced increases in cAMP output were approximately 2-fold greater in preovulatory compared to smaller-sized follicles in FF and ++ genotypes. This increase in cAMP could be explained by an increase in Gs content if it is assumed that the forskolininduced increase was a consequence of activation of the Gs-cyclase complex (Seamon \& Daly, 1985). Alternatively the increase in cAMP could be explained by an increase in the amount of catalytic subunit. In any event, further studies are required to establish whether these or other mechanisms are involved.

The size-specific increase in FSH-, cholera toxin-, forskolin- or cholera toxin + forskolininduced cAMP output in granulosa cells occurs concomitantly with size-specific increases in aromatase activity and the acquisition of plasma membrane receptors for LH (McNatty et al., 1986a, b). Although not proven for sheep, aromatase and LH receptor induction in rodents and pigs appear to be a consequence of FSH stimulation and/or phosphorylation (activation?) of the oestradiol receptor (Richards, 1980; La Barbera \& Ryan, 1981; Richards \& Hedin, 1988). Whether these key follicular events are due to higher plasma LH and/or FSH concentrations in FF compared with ++ ewes (McNatty et al., 1987, 1989c) or to some other gene-specific activity (at present unknown) requires further study.

Irrespective of genotype or follicle size, the rates of cAMP synthesis after FSH, cholera toxin or forskolin stimulation tended to slow down after 40-60 min. After exposure to FSH or forskolin the cAMP responses had increased above the control values after $10 \mathrm{~min}$. For FSH this is consistent with the report that $50 \%$ of the hormone is bound to its receptor after $3 \mathrm{~min}$ at $37^{\circ} \mathrm{C}$ ( $\mathrm{McNatty}$ et al., 1989a). After addition of cholera toxin, there was a $20 \mathrm{~min}$ time-lag before cAMP synthesis began to increase. The lag in cAMP response to cholera toxin has previously been observed in a variety of cell types (e.g. fat cells, Leydig cells, granulosa cells; Sahyoun \& Cuatrecasas, 1975; Dufau et al., 1978; La Barbera et al., 1982). The lag in response has been attributed to the time taken for the initial interaction of cholera toxin with the cell membrane and the release and/or transmembrane passage of the toxin's active subunit before activation of adenylate cyclase (Sahyoun \& Cuatrecasas, 1975; Gill, 1976). In the present report, the incubation time for all but the time-related studies was $45 \mathrm{~min}$; at this time it is reasonable to assume cAMP was being accumulated at a maximum rate notwithstanding the differences in rates of accumulation between cholera toxin and FSH or forskolin during the first $20 \mathrm{~min}$.

Over a time period of 45 min the mean cAMP outputs to the highest doses of cholera toxin $(0.5 \mu \mathrm{g} / \mathrm{ml})$ or FSH $(1 \mu \mathrm{g} / \mathrm{ml})$ were similar. This, together with the finding that the effects of cholera toxin + forskolin or FSH plus forskolin were similar, is consistent with the notion that FSH acts through the same post-receptor stimulator(s) of adenylate cyclase that is targeted by cholera toxin. The finding that the effects of forskolin + cholera toxin were additive with respect to cAMP synthesis is consistent with the view that each substance may target different components of adenylate cyclase (Gilman, 1984). Preliminary studies with granulosa cells from Romney ewes have shown that the highest doses of FSH $(1 \mu \mathrm{g} / \mathrm{ml})$, cholera toxin $(0.5 \mu \mathrm{g} / \mathrm{ml})$ or forskolin $\left(10^{-4} \mathrm{M}\right)$ used in the present study were maximal with respect to cAMP synthesis. However, because higher doses of these substances were not tested against granulosa cells from ++ or FF Booroola ewes, we cannot be certain that the above doses used in the present study always led to a maximal cAMP output. Nevertheless, the additive effects of cholera toxin (or FSH) + forskolin were independent of follicular diameter or Booroola genotype, indicating that hormones such as FSH are unlikely to gain access to the entire pool of adenylate cyclase in granulosa cells.

In conclusion, no evidence was obtained from the present study to suggest that the earlier maturation of follicles in FF compared to ++ ewes is due to gene-specific differences in the cholera toxin-, forskolin- or pertussis toxin-sensitive components of the cAMP-generating system of granulosa cells.

We thank our colleagues at the Invermay Agricultural Research Centre, and in particular, $\mathrm{Mr}$ George Davis for supplying the animals as well as details of their reproductive records; the 
National Institute of Arthritis, Metabolism and Digestive Diseases, USA, for the supply of ovine FSH; Dr K. M. Henderson, Dr C. Price and Mr D. Heath for advice; Dr M. Roberts and Ms S. L. Seah for assistance with statistical analysis; and Mrs S. Dolden for typing the manuscript.

\section{References}

Bindon, B.M. (1984) Reproductive biology of the Booroola Merino sheep. Aust. J. biol. Sci. 37, $163-189$.

Birnbaumer, L., Codina, J., Mattera, G., Cerione, R.A., Hildebrandt, J.D., Sunyer, T., Rojas, F.J., Caron, M.G., Lefkowitz, R.J. \& Iyengar, R. (1985) Regulation of hormone receptors and adenylyl cyclases by guanine nucleotide binding $\mathrm{N}$ proteins. Recent Prog. Horm. Res. 41, 41-94.

Davis, G.H., Montgomery, G.W., Allison, A.J. \& Kelly Bray, A.R. (1982) Segregation of a major gene influencing fecundity in progeny of Booroola sheep in New Zealand. N.Z. Jl agric. Res. 25, 525-529.

Dufau, M., Horner, K.A., Hayashi, K., Tsuruhara, T., Conn, P.M. \& Catt, K.J. (1978) Actions of choleragen and gonadotropin in isolated Leydig cells. J. biol. Chem. 253, 3721-3729.

Gill, D.M. (1976) The arrangements of subunits in Cholera Toxin. Biochemistry, NY 15, 1242-1248.

Gilman, A.G. (1984) $G$ proteins and dual control of adenylate cyclases. Cell 36, 577-579.

Harper, J.F. \& Brooker, G. (1975) Fentomole sensitive radioimmunoassay for cyclic AMP and cyclic GMP after 2 - 0 -acetylation by acetic anhydride in aqueous solution. J. cyclic Nucleotide Res. 1, 207-218.

Henderson, K.M., Kieboom, L.E., McNatty, K.P., Lun, S. \& Heath, D. (1985) Gonadotrophin stimulated cyclic AMP production by granulosa cells from Booroola $\times$ Romney ewes with and without a fecundity gene. $J$. Reprod. Fert. 75, 111-120.

Henderson, K.M., McNatty, K.P., O'Keeffe, L.E., Lun, S., Heath, D.A. \& Pisk, M.D. (1987) Differences in gonadotrophin stimulated cyclic AMP production by granulosa cells from Booroola $\times$ Merino ewes which were homozygous, heterozygous or non-carriers of a fecundity gene influencing their ovulation rate. $J$. Reprod. Fert. 81, 395-402.

Jakobs, K.H., Aktories, K., Minuth, M. \& Schultz, G. (1985) Inhibition of adenylate cyclase. Adv. Cyclic Nucleotide and Protein Phosphorylation Res. 19, 137-150.

La Barbera, A.R. \& Ryan, R.J. (1981) Porcine granulosa cells in suspension culture. 1. Follicle-stimulating hormone induction of human chononic gonadotropin-binding sites in cells from small follicles. Endocrinology 108, 1561-1570.

La Barbera, A.R., Bergert, E.R. \& Ryan, R.J. (1982) Effects of hormones, cholera toxin, and $\alpha$-tosyl-Llysine chloromethyl ketone on adenylate cyclase in viable granulosa cells. Endocrinology 111, 1897-1903.

MeNatty, K.P., Kieboom, L.E., McDiarmid, J., Heath, D.A. \& Lun, S. (1985a) Adenosine cyclic $3^{\prime}, 5^{\prime}$-monophosphate and steroid production by small ovarian follicles from Booroola ewes with and without a fecundity gene. J. Reprod. Fert. 76, 471-480.

McNatty, K.P., Henderson, K.M., Lun, S., Heath, D.A., Ball, K., Hudson, N.L., Fannin, J., Gibb, M., Kieboom, L.E. \& Smith, P. (1985b) Ovarian activity in
Booroola $\times$ Romney ewes which have a major gene influencing their ovulation rate. J. Reprod. Fert. 73, $109-120$.

McNatty, K.P., Lun, S., Heath, D.A., Ball, K., Smith, P., Hudson, N.L., McDiarmid, J., Gibb, M. \& Henderson, K.M. (1986a) Differences in ovarian activity between Booroola $\times$ Merino ewes which were homozygous, heterozygous and non-carriers of a major gene influencing their ovulation rate. J. Reprod. Fert. 77, 193-205.

McNatty, K.P., O'Keeffe, L.E., Henderson, K.M., Heath, D.A. \& Lun, S. (1986b) ${ }^{125}$ I-labelled hCG binding characteristics in theca interna and other tissues from Romney ewes and from Booroola $\times$ Romney ewes with and without a major gene influencing their ovulation rate. $J$. Reprod. Fert. $77,477-488$.

McNatty, K.P., Hudson, N., Henderson, K.M., Gibb, M., Morrison, L., Ball, K. \& Smith, P. (1987) Differences in gonadotrophin concentrations and pituitary responsiveness to $\mathrm{GnRH}$ between Booroola ewes which were homozygous (FF), heterozygous $(\mathrm{F}+)$ and non-carriers $(++)$ of a major gene influencing their ovulation rate. $J$. Reprod. Fert. 80, 577-588.

McNatty, K.P., Lun, S., Heath, D.A., Hudson, N.L., O'Keeffe, L.E. \& Henderson, K.M. (1989a) ${ }^{125}$ Ilabelled hFSH binding characteristics of granulosa cells from Booroola ewes which were homozygous, heterozygous or non-carriers of a major gene(s) influencing their ovulation rate. J. Reprod. Fert. 86, 27-38.

McNatty, K.P., Heath, D.A., Lun, S. \& Hudson, N.L. (1989b) Adenosine 3',5'-cyclic monophosphate phosphodiesterase activity in granulosa cells from Booroola $\times$ Romney ewes with and without the $F$ gene. J. Endocr. 120, 287-293.

McNatty, K.P., Fisher, M., Collins, F., Hudson, N.L., Heath, D.A., Ball, K. \& Henderson, K.M. (1989c) Differences in the plasma concentrations of FSH and LH in ovariectomized Booroola FF and ++ ewes. $J$. Reprod. Fert. 85, 705-713.

Richards, J.S. (1980) Maturation of ovarian follicles: action and interactions of pituitary and ovarian hormones on follicular cell differentiation. Physiol. Rev. 60, 51-89.

Richards, J.S. \& Hedin, L. (1988) Molecular aspects of hormone action in ovarian follicular development, ovulation and luteinization. Ann. Rev. Physiol. 50, $577-579$

Sahyoun, N. \& Cuatrecasas, P. (1975) Mechanisms of activation of adenylate cyclase by cholera toxin. Proc. natn. Acad. Sci. USA 72, 3438-3442.

Schram, M. \& Selinger, Z. (1986) Message transmission: receptor controlled adenylate cyclase system. Science, NY 225, 1350-1356.

Seamon, K.B. (1985) Activation of hormone-sensitive adenylate cyclase by Forskolin. Drug Dev. Res. 6, 181-192.

Downloaded from Bioscientifica.com at 04/26/2023 01:31:13PM 
Seamon, K.B. \& Daly, J.W. (1985) High affinity binding of Forskolin to rat brain membranes. Adv. Cyclic Nucleotide and Protein Phosphorylation Res. 19, 125-135.

Seamon, K.B., Padgett, W. \& Daly, J.W. (1981) Forskolin: unique diterpene activator of adenylate cyclase in membranes and in intact cells. Proc. natn. Acad. Sci. USA 78, 3363-3367.

Sorger, T. \& Germinario, R.J. (1983) A direct solubilization procedure for the determination of DNA and protein in cultured fibroblast monolayers. Analyt. Biochem. 131, 254-256.

Veldhuis, J.D. \& Hewlett, E.L. (1985) Evidence for a functionally active inhibitory guanine nucleotide-binding regulatory protein in the swine ovary. Biochem. Biophys. Res. Commun. 131, 1168-1174.

Zar, J.H. (1974) Biostatistical Analysis, pp. 80-82. Prentice-Hall Inc., Englewood Cliffs.

Received 11 October 1989 